\title{
KONTRIBUSI PEMBINAAN KEPALA KEMENTERIAN AGAMA DAN KOMPETENSI PENGAWAS TERHADAP PELAKSANAAN KOMPETENSI PROFESIONAL GURU PAI
}

\author{
Faisal \\ Kementerian Agama Kota Bandung, Indonesia \\ *E-mail:f165sal@gmail.com
}

\begin{abstract}
This study aims to determine the contribution of the guidance of the head of the Ministry of Religious Affairs and the competence of supervisors to the implementation of the professional competence of Islamic Religious Education (IRE) teachers. The method used in this research is quantitative analysis based on statistical inferential models. The data collection was done using observation, interviews, and questionnaires. After the data is collected, it is then processed using logical analysis for qualitative and statistical analysis for quantitative data using descriptive statistics, regression, and correlation. Based on the hypothesis test, the guidance of the Head of the Ministry of Religious Affairs and the competence of supervisors contributes positively and significantly to the implementation of the professional competence of Islamic Religious Education (IRE) teachers.
\end{abstract}

Keywords: Supervisory Competence, Islamic Religious Education (IRE), Teacher Professional Competence.

\begin{abstract}
Abstrak. Penelitian ini bertujuan untuk mengetahui kontribusi pembinaan kepala Kementerian Agama dan kompetensi pengawas terhadap pelaksanaan kompetensi profesional guru Pendidikan Agama Islam (PAI). Metode yang digunakan dalam penelitian ini adalah analisis kuantitatif berbasis model statistika inferensia. Adapun pengumpulan datanya dilakukan dengan menggunakan teknik observasi, wawancara, dan angket. Setelah data terkumpul, kemudian diolah dengan menggunakan analisis logika untuk kualitatif dan analisis statistika untuk data kuantitatif dengan menggunakan statistik deskriptif, regresi, dan korelasi. Berdasarkan uji hipotesis, pembinaan Kepala Kemenag dan kompetensi pengawas berkontribusi secara positif dan signifikansi terhadap pelaksanaan kompetensi profesional guru PAI.
\end{abstract}

Kata kunci: Supervisi Pendidikan Agama Islam; Profesionalisme; Pendidikan Agama Islam (PAI). 


\section{PENDAHULUAN}

Secara fungsional, guru merupakan fasilitator yang bertugas untuk mentransfer kemampuannya (kompetensi) kepada peserta didik. Menurut Supriadi (1999) peserta didik memiliki tuntutan kepada gurunya untuk kompeten dan dapat menyampaikan apa yang diajarkannya dengan jelas sehingga dapat memenuhi kebutuhan peserta didik, dan bukan hanya kebutuhan program. Menurut Yusuf (2013) guru yang didefinisikan sebagai mudarris mempunyai tugas dan kewajiban menjadikan pembelajaran yang membekas dalam jiwa peserta didik. Bekas itu merupakan hasil pembelajaran yang berwujud perubahan perilaku, sikap, dan penambahan atau pengembangan ilmu pengetahuan mereka.

Disamping itu, guru yang sering diungkapkan sebagai sosok yang patut digugu dan ditiru oleh peserta didiknya merupakan ungkapan yang sederhana namun memiliki nilai filosofis tinggi. Guru dianggap dapat dijadikan sebagai nilai untuk mewujudkan pelaksanaan kompetensinya. Apalagi mengingat problematika yang dihadapi sekolah secara umum berkaitan dengan problematika nilai (Fakhruddin, 2014). Selain itu, guru juga memiliki tanggung jawab dalam perkembangan peserta didik untuk mengupayakan mengembangkan seluruh potensi peserta didik baik potensi kognitif, afektif, dan psikomotor.

Untuk mencapai eksistensi guru tersebut, guru membutuhkan bimbingan dan pelatihan. Melalui proses bimbingan dan pelatihan guru menempati peranan kunci dalam mengelola kegiatan pembelajaran. Peranan kunci ini dapat diemban apabila guru tersebut memiliki tingkat kemampuari profesional yang tinggi (Dirjen Pembinaan Kelembagaan Agama Islam, 2001).

Proses bimbingan dan pelatihan ini merupakan bagian integral dari manajemen mutu pendidikan. Manajemen mutu pendidikan sebagai bagian dari manajemen pendidikan memiliki peran strategis dalam pencapaian tujuan pendidikan. Apalagi mengingat manajemen pendidikan merupakan salah satu faktor yang akan mempengaruhi maju mundurnya suatu organisasi (Fakhruddin, 2011; Fahrudin, 2011).

Demikian halnya dengan Guru Pendidikan Agama Islam (PAI). Untuk menjamin kualitas guru PAI dibutuhkan bimbingan dan pelatihan yang berkelanjutan. Untuk meningkatkan pelaksanaan kompetensi profesional guru PAI, perlu adanya tanggung jawab bersama dalam pendidikan.

Tanggung jawab pendidikan bagi guru PAI diantaranya melalui pembinaan kepala kanwil kemenag melalui kepala kemenag kab/kota (PMA no 2 tahun 2012 pasal 19 ayat 2) terhadap pengawas. Lima kompetensi pengawas:1. Kompetensi kepribadian; 2. Kompetensi supervisi akademik; 3. Kompetensi evaluasi pendidikan; 4. Kompetensi penelitian dan pengembangan; 5 . Kompetensi sosial (PMA no 2 tahun 2012 pasal 8 ayat 2). Proses itu dilaksanakan secara kontinyu sehingga menghasilkan pelaksanaan kompetensi profesional guru PAI.

Tanggung jawab terpenting di dalam pelaksanaan kompetensi profesional guru 
PAI yaitu: Pengawas PAI pd sekolah sesuai dengan pasal 2 ayat 2 (PMA no 2 tahun 2012) berwenang: (1) Memberikan masukan, saran dan bimbingan; evaluasi pendidikan dan/atau pembelajaran PAI kepada kepala sekolah dan instansi yang membidangi urusan pendidikan tingkat kota/kab; (2) Memantau dan menilai kinerja guru PAI; (3) Melakukan pembinaan kepada GPAI; (4) Memberikan pertimbangan dalam penilaian pelaksanaan tugas GPAI kepada pejabat yang berwenang; (5) Memberikan pertimbangan dalam penilaian pelaksanaan tugas dan penempatan GPAI kepada pejabat yang berwenang.

Keberadaan Pengawas sendiri
memiliki peranan penting dalam peningkatan kompetensi professional guru PAI, apalagi mengingat betapa urgennya supervisi bagi para guru di era 4.0 ini (Rofiki, 2019), terutama supervisi pengajaran/akademik (Sarnoto, 2012). Dalam praktiknya hal itu memang tidak mudah, apalagi mengingat problematika yang dihadapi dalam supervisi kepada para guru ini yang kompleks seperti problematika yang berkaitan dengan teknik edukatif, teknik administrative, dan teknik kerja sama (Nurmayuli, 2018), selain problematika lainnya seperti proses kegiatan supervisi akademik yang belum berjalan dengan baik, situasi daerah kepengawasan yang tidak mendukung, pengawas PAI yang tidak menguasai materi bimbingan, serta budaya sekolah yang kurang baik (Nopriyani, 20160.

Berkenaan dengan latar belakang masalah tersebut, maka dipandang perlu untuk dilakukan penelitian tentang Kontribusi Pembinaan Kepala Kemenag dan Kompetensi Pengawas terhadap Pelaksanaan Kompetensi Profesional Guru PAI (penelitian pada guru PAI SMA Kota Bandung) untuk mendapatkan informasi tentang seberapa besar kontribusinya.

\section{Pembinaan Kepala Kemenag}

Pembinaan menurut (Mathis, 2002), adalah suatu proses dimana orang-orang mencapai kemampuan tertentu untuk membantu mencapai tujuan organisasi. Oleh karena itu, proses ini terkait dengan berbagai tujuan organisasi, pembinaan dapat dipandang secara sempit maupun luas. Sedangkan (Ivancevich, 2008) mendefinisikan pembinaan sebagai usaha untuk meningkatkan kinerja pegawai dalam pekerjaannya sekarang atau dalam pekerjaan lain yang akan dijabatnya segera.

Dalam konteks guru PAI, keberadaan kementerian agama sebagai lembaga yang menaunginya sangatlah penting. Kementerian agama merupakan salah lembaga pemerintah yang memiliki tugas untuk mengawasi pelaksanaan pendidikan di madrasah/sekolah. Pembinaan yang dilaksanakan oleh Kepala kantor secara terprogram yang didasari oleh tanggung jawab sebagai atasan langsung pengawas PAI merupakan faktor utama peningkatan kompetensi pengawas PAI. Untuk mencapai kompetensi professional guru PAI, kontribusi kementerian agama ini sangatlah dibutuhkan.

Pelaksanan kompetensi profesional guru tergantung kepada kompetensi pengawas, karena tugas pokok pengawas adalah melaksanakan tugas pengawasan akademik dan manjerial pada satuan pendidikan yang meliputi; penyusunan 
program pengawasan, pelaksanaan pembinaan, pemantauan pelaksanaan 8 (delapan) Standar Nasional Pendidikan, penilaian, pembimbingan dan pelatihan profesional guru, evaluasi hasil pelaksanaan program pengawasan dan pelaksanaan tugas kepengawasan di daerah khusus. (Permenpan-RB Bab II pasal 5).

\section{Kompetensi Pengawas}

Dalam kegiatan pengawasan, unsur pembinaan dan kompetensi pengawas keduanya tidak dapat dipisahkan tetapi dapat dibedakan. Dalam pembinaan pengawas sebuah proses untuk mengubah perilaku kerja seorang/ sekelompok pegawai dalam usaha meningkatkan kinerja organisasi. Pembinaan terkait dengan keterampilan dan kemampuan yang diperlukan untuk pekerjaan yang sekarang dilakukan. Pembinaan berorientasi ke masa sekarang dan membantu pegawai untuk menguasai keterampilan dan kemampuan (kompetensi) yang spesifik untuk berhasil dalam pekerjaannya (Ivancevich, 2008).

Kompetensi pengawas mencakup kemampuan yang direfleksikan pada pengetahuan, sikap, dan keterampilan dalam melaksanakan tugas-tugas pokok dan fungsi jabatan profesional sebagai pengawas sekolah (Sudjana, 2012). Dengan melihat kemampuan yang harus dimiliki pengawas maka pengawas dituntut untuk mengembangkan tugas pokok dan fungsi sebagai supervisor.

Kompetensi pengawas yang harus dikuasai seorang pengawas mencakup kompetensi keperibadian, supervisi manajerial, supervisi akademik, evaluasi pendidikan, dan sosial, kompetensi penelitian dan pengembangan. Kompetensi tersebut dalam praktiknya masih belum sepenuhnya terpenuhi. Penyelenggaraan pendidikan dan latihan bagi pengawas adalah solusi strategis dan paling efektif dalam upaya peningkatan enam kompetensi yang diamanatkan oleh Peraturan Menteri Pendidikan Nomor 12 tahun 2007 dan Peraturan Menteri Agama Nomor 31 tahun 2013 tentang perubahan atas PMA nomor 2 tahun 2012 tentang pengawas madrasah dan pengawas PAI-sekolah (Aguslani, 2019).

Agar kompetensi pengawas tersebut dapat teraktualisasikan, maka seorang pengawas harus memberikan peran dalam melaksanakan tugas dan fungsinya. Peran pengawas dalam pengawasan dilaksanakan melalui pendekatan supervisi yang bersifat ilmiah, klinis, manusiawi, kolaboratif, artistik, interpretatif, dan berbasis kondisi sosial budaya (Mulyadi, 2020).

\section{Kompetensi Profesional Guru PAI}

Kompetensi profesional penting dimiliki oleh seorang guru. Sebagaimana yang tertuang dalam UU RI No. 14/2005 Pasal 10 ayat 1 dan PP RI No. 19/2005 Pasal 28 ayat 3: "Kompetensi profesional guru diartikan sebagai kebulatan pengetahuan, kete-rampilan, dan sikap yang diwujudkan dalam bentuk tindakan cerdas dan penuh tanggung jawab yang dimiliki seseorang yang memangku jabatan guru sebagai profesi". Kompetensi profesional senantiasa dikaitkan dengan kemampuan dalam menguasai materi dan metodologi pembelajarannya. 
Kompetensi profesional guru PAI dalam pandangan Tafsir (1991), menegaskan bahwa jabatan profesional kependidikan Islam, yakni: 1) profesi harus memiliki keahlian yang bersifat khusus, 2) profesi harus diambil sebagai pemenuhan panggilan hidup atau panggilan atas pengabdiannya kepada masyarakat, 3) profesi memiliki teoriteori yang baku secara universal, yang berkaitan dengan keahlian sebagai tersebut di atas, 4) profesi adalah untuk masyarakat sebagai alat pengabdian diri kepada masyarakat bukan untuk kepentingan diri pribadi, mengejar jabatan atau kedudukan, 5) profesi harus dilengkapi dengan kecakapan dan kompetensi aplikatif, 6) pemegang profesi memiliki otonomi dalam melakukan tugas profesinya, 7) profesi hendaknya memiliki kode etik, 8) profesi hendaknya mempunyai klien yang jelas, 9) profesi memerlukan organisasi profesi, 10) profesi hendaknya mengenali hubungan antara profesinya dengan bidang-bidang lain.

Untuk meningkatkan kompetensi guru PAI perlu diberikan langkah-langkah pengembangan. Beberapa langkah pengembangan kompetensi profesionalisme guru diantaranya melalui belajar mandiri, mengikuti pelatihan individu, diskusi dan rapat dewan guru, melakukan penguatan melalui kegiatan Kerja Kelompok Guru, serta melakukan pusat kegiatan guru pada tingkat kecamatan (Buto, 2016).

Upaya pengembangan itu dilakukan untuk menanggulangi lemahnya kompetensi guru PAI meski dalam pelaksanaannya terdapat kendala. Beberapa kendala dalam pengembangan diantaranya ditemukan bahwa kendala utama pengembangan kompetensi profesionalisme guru adalah pelatihan guru berjalan di tempat, kurangnya alokasi dana peningkatan guru, terjadinya penurunan motivasi, dan kurangnya penguasaan informasi dan teknologi (Buto, 2016).

\section{METODE PENELITIAN}

Berdasarkan karakteristik data penelitian yang akan dicari, diolah, dan dianalisis bersifat kuantitatif, maka penelitian ini sangat tepat menggunakan pendekatan kuantitatif. Penelitian ini termasuk jenis penelitian eksplanatoris (explanatory research). Penelitian eksplanatori yaitu penelitian yang menjelaskan hubungan kausal antara variabel-variabel yang mempengaruhi hipotesis. Pada penelitian ini minimal terdapat dua variabel yang dihubungkan dan penelitian ini berfungsi menjelaskan, meramalkan dan mengontrol suatu gejala. Dalam penelitian ini akan dijelaskan mengenai adanya hubungan interaktif atau timbal balik dan saling mempengaruhi antara variabel yang akan diteliti. Penelitian ini menghubungkan 3 (tiga) variabel, yaitu pembinaan kepala kemenag sebagai variabel bebas (Independent variable, dengan notasi statistik $\mathrm{X}_{1}$ ) dan kompetensi pengawas sebagai variabel bebas (Independent variable, dengan notasi statistik $\mathrm{X}_{2}$ ), sedangkan pelaksanaan kompetensi profesional gpai sebagai variabel terikat (Dependent variable, dengan notasi statistik Y).

Penelitian ini dilaksanakan kepada para guru PAI SMA Kota Bandung. Pemilihan lokasi ini didasarkan pada masalah pembinaan dan kompetensi 
pengawas. Sampel penelitian ditentukan secara purposive. Menurut Sugiyono (2013) sampel purposive adalah teknik penentuan sampel dengan pertimbangan tertentu. Dalam hal ini sampel penelitian diambil dari guru PAI yang berjumlah 48 orang di SMA kota Bandung, Jawa Barat Indonesia. Pola pembahasan dalam penelitian ini menggunakan model yang dikembangkan oleh Ramdhani et al (2014).

\section{HASIL PENELITIAN DAN PEMBAHASAN}

Hipotesis utama yang diuji dalam penelitian ini adalah "Terdapat Kontribusi Pembinaan Kepala Kemenag dan Kompetensi Pengawas terbadap Pelaksanaan Kompetensi Profesional Guru PAI”. Adapun paradigma penelitian yang diajukan dalam penelitian ini sebagaimana tersaji pada Gambar 1.

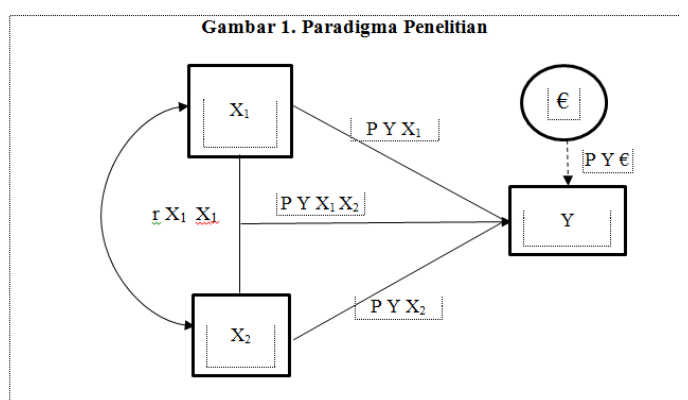

Tabel 1: Descr iptive Statistic:

Kontribusi Pembinaan Kepala Kemenag dan Kompetensi Pengawas terhadap Pelaksanaan Kompetensi Profesional Guru PAI

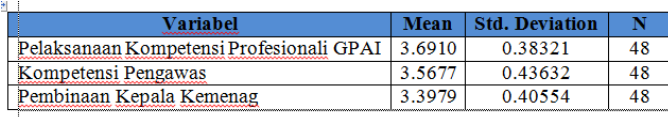

Pada tabel 1. memberikan inforrnasi mengenai besarnya mean (rata-rata) dan simpangan baku (standard deviation) setiap variabel. Rata-rata variabel pelaksanaan kompetensi profesional guru PAI adalah 3.6910. Rata-rata variabel kompetensi pengawas adalah sebesar 3.5677. Ratarata variabel pembinaan kepala kemenag adalah 3.3979. Simpangan baku variabel pelaksanaan kompetensi profesional guru PAI adalah 0.38321. Simpangan baku untuk kompetensi pengawas adalah 0.43632. Sedangkan simpangan baku untuk variabel pembinaan kepala kemenag adalah 0.40554 .

\section{Tabel 2: Correlations:}

Kontribusi Pembinaan Kepala Kemenag dan Kompetensi Pengawas terhadap Pelaksanaan Kompetensi Profesional Guru PAI.

\begin{tabular}{|c|c|c|c|c|}
\hline Variabel & & $\begin{array}{c}\text { Pelaksanaan } \\
\text { Kompetensi } \\
\text { Profesionali } \\
\text { GPAI }\end{array}$ & \begin{tabular}{c|} 
Pembinaan \\
Kepala \\
Kemenag
\end{tabular} & $\begin{array}{c}\text { Kompetensi } \\
\text { Pengawas }\end{array}$ \\
\hline \multirow{3}{*}{$\begin{array}{l}\text { Pearson } \\
\text { Correlation }\end{array}$} & $\begin{array}{l}\text { Pelaksanaan } \\
\text { Kompetensi } \\
\text { Profesional GPAI }\end{array}$ & 1.000 & .506 & .611 \\
\hline & Kompetensi Pengawas & 0.506 & 1.000 & .427 \\
\hline & $\begin{array}{ll}\text { Pembinaan } & \text { Kepala } \\
\text { Kemenag }\end{array}$ & .611 & .427 & 1.000 \\
\hline \multirow{3}{*}{$\begin{array}{l}\text { Sig. (1- } \\
\text { tailed) }\end{array}$} & $\begin{array}{l}\text { Pelaksanaan } \\
\text { Kompetensi } \\
\text { Profesional GPAI }\end{array}$ & - & 0.000 & 0.000 \\
\hline & Kompetensi Pengawas & 0.000 & - & 0.001 \\
\hline & $\begin{array}{l}\text { Pembinaan Kepala } \\
\text { Kemenag }\end{array}$ & 0.000 & 0.001 & - \\
\hline \multirow{3}{*}{$\mathrm{N}$} & $\begin{array}{l}\text { Pelaksanaan } \\
\text { Kompetensi } \\
\text { Profesional GPAI }\end{array}$ & 48 & 48 & 48 \\
\hline & Kompetensi Pengawas & 48 & 48 & 48 \\
\hline & $\begin{array}{l}\text { Pembinaan } \\
\text { Kemenag }\end{array}$ & 48 & 48 & 48 \\
\hline
\end{tabular}

Tabel 2. menunjukkan nilai korelasi Product Moment. Nilai korelasi $\mathrm{X}_{1}$ dengan $\mathrm{Y}$ sebesar 0.506 dengan nilai $p$ value (Sig.) sebesar 0.000. Dengan demikian dapat dikatakan terdapat hubungan yang kuat (dengan arah positif) dan signiflkan (karena nilai $p$ value $<0.05$ ) antara pembinaan kepala kemenag dengan pelaksanaan kompetensi profesional guru PAI. Nilai korelasi $\mathrm{X}_{2}$ dengan $\mathrm{Y}$ sebesar 0.611 dengan nilai $p$ value (Sig.) sebesar 
0.000. Dengan demikian dapat dikatakan terdapat hubungan yang kuat (dengan arah positif) dan signifikan (karena nilai $p$ value $<0.05)$ antara kompetensi pengawas dengan pelaksanaan kompetensi profesional guru PAI. Hubungan positif ini mengindikasikan bahwa semakin tinggi kontribusi pembinaan kepala kemenag, maka akan semakin tinggi pula pelaksanaan kompetensi profesional guru PAI. Begitu juga, semakin tinggi kontribusi kompetensi pengawas, maka akan semakin tinggi pula pelaksanaan kompetensi profesional guru PAI. Secara teoritis, berdasarkan nilai korelasi dapat dikatakan bahwa kompetensi pengawas lebih berpengaruh terhadap pelaksanaan kompetensi profesional guru PAI.

\begin{tabular}{|c|c|}
\hline Interkorelasi & Tingkat Hubungan \\
\hline $0.80-1.00$ & Sangat Kuat \\
\hline $0.60-0.79$ & Kuat \\
\hline $0.40-0.59$ & Cukup Kuat \\
\hline $0.20-0.39$ & Lemah \\
\hline $0.00-0.19$ & Sangat Lemah \\
\hline
\end{tabular}

Tabel 4: Model Summary:

Kontribusi Pembinaan Kepala Kemenag dan Kompetensi Pengawas terhadap Pelaksanaan Kompetensi Profesional Guru PAI.

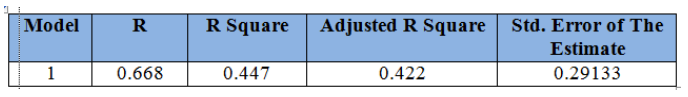

a. Predictors: (Constant), kompetensi pengawas, pembinaan kepala kemenag.

b. Dependent Variable: pelaksanaan kompetensi guru PAI

Berdasarkan nilai $\mathrm{R}$ pada Tabel 4 . dapat diketahui bahwa besarnya koefisien regresi antara pembinaan kepala kemenag dan kompetensi pengawas dengan pelaksanaan kompetensi profesional guru PAI adalah sebesar 0.668 (kuat). Nilai R square sebesar 0.447 (menunjukkan kontribusinya $0.447 \times 100 \%)$. Hal ini menunjukkan bahwa besarnya kontribusi variabel pembinaan kepala kemenag dan kompetensi pengawas dalam memberikan kontribusi bagi variabel pelaksanaan kompetensi profesional guru PAI adalah $44.7 \%$, sedangkan sisanya sebesar $55.3 \%$ dipengaruhi oleh ariabel atau faktor lain. Semakin tinggi nilai $\mathrm{R}$ maka semakin tinggi hubungan dua variabel.

\section{Tabel 5: Anova}

Kontribusi Pembinaan Kepala Kemenag dan Kompetensi Pengawas terhadap Pelaksanaan Kompetensi Profesional Guru PAI

\begin{tabular}{|l|c|c|c|c|c|}
\hline \multicolumn{1}{|c|}{ Model } & $\begin{array}{c}\text { Sum of } \\
\text { Squares }\end{array}$ & Df & Mean Squares & F & Sig. \\
\hline Regression & 3.083 & 2 & 1.541 & 18.159 & 0.000 \\
\hline Residual & 3.819 & 45 & 0.085 & 0 & 0 \\
\hline Total & 6.902 & 47 & 0 & 0 & 0 \\
\hline
\end{tabular}

a. Predictors: (Constant), pembinaan kepala kemenag, kompetensi pengawas.

b. Dependent Variable: pelaksanaan kompetensi profesional guru PAI

Tabel Anova digunakan untuk menentukan taraf signifikansi atau linieritas dari regresi. Kriterianya dapat ditentukan dari uji $\mathrm{F}$ atau uji signifikansi (Sig.) dengan ketentuan jika nilai Sig. < 0.05 , maka model regresi adalah linier dan berlaku sebaliknya. Berdasarkan tabel Anova di atas, dijelaskan bahwa nilai $\mathrm{F}=$ 18.159 dengan tingkat probabilitas Sig. 0.000 . Oleh karena probabilitas $(0.000)$ jauh lebih kecil dari 0.05, dengan demikian model persamaan regresi signifikan, artinya model regresi linier memenuhi kriteria linieritas.

Tabel 6: 
Coefficients; Kontribusi Pembinaan

Kepala Kemenag dan Kompetensi

Pengawas terhadap Pelaksanaan

Kompetensi Profesional Guru PAI.

\begin{tabular}{|l|c|c|c|c|c|}
\hline \multirow{2}{*}{ Model } & \multicolumn{2}{|c|}{$\begin{array}{c}\text { Unstandardized } \\
\text { Coefficients }\end{array}$} & $\begin{array}{c}\text { Standardi } \\
\text { zed } \\
\text { Coeffients }\end{array}$ & \multirow{2}{*}{ t } & \multirow{2}{*}{ Sig. } \\
\cline { 2 - 6 } & $\mathrm{B}$ & $\begin{array}{c}\text { Std. } \\
\text { Error }\end{array}$ & $\begin{array}{c}\text { Beta } \\
\end{array}$ & & \\
\hline 1. (Constant) & 1.202 & 0.419 & 0 & 2.871 & 0.006 \\
2. Pembinaan Kepala Kemenag. & 0.263 & 0.108 & 0.300 & 2.445 & 0.018 \\
3. Kompetensi Pengawas & 0.456 & 0.116 & 0.483 & 3.935 & 0.000 \\
\hline
\end{tabular}

a. Dependent Variable: Pelaksanaan Kompetensi Profesional Guru PAI

Tabel coefficients di atas menunjukkan persamaan garis regresi. Rumus persamaan garis regresi secara umum adalah:

$\mathrm{Y}=\mathrm{a}+\mathrm{b}_{1} \mathrm{X}_{1}+\mathrm{b}_{2} \mathrm{X}_{2}$

Tabel coeffcients di atas menunjukkan rumus persamaan garis regesi

$\mathrm{Y}=0.1202+0.263 \mathrm{x}_{\mathrm{I}}+0.456 \mathrm{x}_{2}$

Artinya apabila pembinaan kepala kemenag $=0\left(\mathrm{X}_{1}=0\right)$ dan kompetensi pengawas $=0\left(X_{1}=0\right)$, maka pelaksanaan kompetensi guru PAI adalah 0.1202 kasus.

Koefisien regresi sebesar 0.300 menyatakan bahwa setiap penambahan (karena tanda + ) satu kasus pembinaan kepala kemenag, akan menambah terhadap pelaksanaan kompetensi guru PAI sebesar 0.300 kasus dan begitupun sebaliknya. Jadi, tanda + menyatakan arah hubungan yang searah, kenaikan atau penurunan variabel perhatian orang tua $\left(\mathrm{X}_{\mathrm{l}}\right)$ akan mengakibatkan penaikan atau penurunan variabel pelaksanaan kompetensi profesional guru PAI (Y).

Koefisien regresi sebesar 0.483 menyatakan bahwa setiap penambahan (karena tanda + ) satu kasus kompetensi pengawas, akan menambah terhadap pelaksanaan kompetensi profesional guru
PAI sebesar 0.483 kasus dan begitupun sebaliknya. Jadi, tanda + menyatakan arah hubungan yang searah, kenaikan atau penurunan variabel kompetensi pengawas $\left(\mathrm{X}_{2}\right)$ akan mengakibatkan penaikan atau penurunan

variabel pelaksanaan kompetensi profesional guru PAI (Y).

Uji Hipotesis utama dilakukan berdasarkan uji $\mathrm{F}$ sebagai berikut:

$\mathrm{H}_{\mathrm{I}}$ : Terdapat kontribusi pembinaan kepala kemenag dan kompetensi pengawas terhadap pelaksanaan kompetensi profesional guru PAI.

$\mathrm{H}_{\mathrm{o}}$ : Tidak terdapat kontribusi pembinaan kepala kemenag dan kompetensi pengawas terhadap pelaksanaan kompetensi profesional guru PAI.

Kaidah keputusan: jika nilai $\mathrm{F}$ hitung lebih besar atau sama dengan $\mathrm{F}_{\text {tabel }}\left(\mathrm{F}_{\text {hitung }}\right.$ $\left.\geq \mathrm{F}_{\text {tabee }}\right)$, maka $\mathrm{H}_{\mathrm{o}}$ ditolak dan $\mathrm{H}_{\mathrm{I}}$ diterima, artinya signifikan. Jika nilai $\mathrm{F}$ hitung lebih kecil atau sama dengan $\mathrm{F}_{\text {tabel }}\left(\mathrm{F}_{\text {hitung }} \leq \mathrm{F}\right.$ tabel), maka $\mathrm{H}_{\mathrm{o}}$ diterima dan $\mathrm{H}_{\mathrm{I}}$ ditolak, artinya tidak signifikan.

Dari tabel 5, diperoleh $\mathrm{F}$ hitung =18.159. adapun nilai $\mathrm{F}_{\text {tabel }}$ untuk $\mathrm{dk}_{\text {Res }}=$ 48 (penyebut), $\mathrm{dk}_{\mathrm{Reg}}=2$ (pembilang) adalah 2.80. $\mathrm{F}_{\text {tabel }}(2.80)(\mathrm{a}=0.05)$ adalah 2.80. Ternyata $\mathrm{F}_{\text {hitung }}>\mathrm{F}_{\text {tabel }}(18.159>$ 2.80), maka $H_{o}$ ditolak dan $H_{I}$ diterima, artinya temapat pengaruh positif dan signifikan dari pembinaan kepala kemenag dan kompetensi pengawas terhadap pelaksanaan kompetensi profesional guru PAI.

Berkenaan dengan teori kompetensi profesional guru PAI yang telah dijabarkan di atas, dapat diketahui bahwa 
pelaksanaan kompetensi profesional guru PAI dapat terlaksana dikarenakan faktor kepemimpinan (pengaruh dan timbal balik) diambil dari Grimes (1978) dan Hollander ((1978) (Shaun T \& Tony J, 2001).

Dua Faktor yang memberikan kontribusi bagi pelaksanaan kompetensi profesional guru PAI, pertama: pembinaan kepala kemenag. Pembinaan kepala kemenag terhadap pengawas berupa pengarahan, bimbingan, dan nasehat. Pembinaan kepala kemenag sangat berkontribusi pada diri pengawas terutama dalam peningkatan kompetensi kepengawasan. Karena dengan memperhatikan pembinaan kepala kemenag kepada pengawas secara berkala akan tumbuh dan berkembang kompetensi pengawas. Kedua, yang mempengaruhi pelaksanaan kompetensi profesional guru PAI adalah kompetensi pengawas. Gordon (1988 : 109) menjelaskan beberapa dimensi yang terkandung dalam konsep kompetensi adalah; l) understanding atau pemahaman, yaitu kedalaman kognitif yang dimiliki seseorang, 2) skill atau kemampuan, yaitu sesuatu keterampilan atau bakat yang dimiliki oleh individu untuk melakukan pekerjaan yang dibebankan kepadanya, 3) knowledge atau pengetahuan, yaitu kesadaran dalam bidang kognitif, yang berarti mengetahui apa yang harus diperbuat, 4) interest atau minat, yaitu kecenderungan seseorang yang tinggi terhadap sesuatu atau untuk melakukan perbuatan sesuatu, 5) attitude atau sikap, yaitu reaksi seseorang terhadap rangsangan yang datang dari luar, misal; rasa senang, suka atau tidak suka, 6) value atau nilai, yaitu suatu standar perilaku atau sikap yang dipercaya secara psikologis telah menyatu dalam diri seseorang

(http://www.pengertianmenurutparaahli. net/pengertian-kompeten-dan-

kompetensif).

Faktor eksternal yang berkontribusi bagi pelaksanaan kompetensi profesional guru PAI adalah dengan mengikuti pelatihan yang dilaksanakan oleh instansi yang terkait, seperti; Pelatihan Penulisan dan Pengembangan Budaya Literasi (PTK, Nulis Buku, Artikel, dll), Pelatihan Pembuatan Media Pembelajaran Kreatif. Latihan (training) dimaksudkan untuk memperbaiki penguasaan berbagai keterampilan dan teknik pelaksanaan kerja tertentu, terinci dan rutin. Yaitu latihan menyiapkan para karyawan (tenaga kerja) untuk melakukan pekerjaan-pekerjaan sekarang (Hani $\mathrm{T}$ Handoko, 2001)

Melalui kelompok rekan kerja (MGMP), guru menerima umpan balik mengenai kemampuan mereka. Guru akan belajar tentang apa yang mereka lakukan lebih baik, sama baiknya, atau bahkan lebih buruk dari apa yang dilakukan guru lain. Musyawarah Guru Mata Pelajaran (MGMP) PAI mempunyai tugas mewadahi bagi rekan-rekan guru melalui pengembangan kompetensi. Pelaksanaan pengembangan cenderung lebih bersifat formal, menyangkut antisipasi kemampuan dan keahlian individu yang harus dipersiapkan bagi kepentingan jabatan yang akan datang. Sasaran dan program pengembangan menyangkut aspek yang lebih luas yaitu peningkatan kemampuan individu untuk mengantisipai perubahan yang mungkin terjadi tanpa direncanakan (unplened change) 
atau perubahan yang direncanakan (planed change) (Syafaruddin, 2001).

\section{KESIMPULAN}

Kontribusi pembinaan kepala kemenag dan kompetensi pengawas terhadap pelaksanaan kompetensi profesional guru PAI di SMA wilayah kota Bandung adalah sebesar $44.7 \%$. Berdasarkan nilai $\mathrm{R}$, dapat diketahui bahwa besarnya koefisien regresi antara kompetensi pengawas dengan pelaksanaan kompetensi profesional guru PAI adalah sebesar 0.668 (kuat). Nilai R square sebesar 0.447 . Hal ini menunjukkan bahwa besarnya kontribusi variabel pembinaan kepala kemenag dalam mempengaruhi pelaksanaan kompetensi profesional guru PAI adalah sebesar $44.7 \%$, sedangkan sisanya sebesar $55.3 \%$ dipengaruhi oleh variabel atau faktor lain yang tidak dilibatkan dalam model penelitian.

\section{REFERENSI}

Aguslani. (2019). Analisis Enam Kompetensi Pengawas Madrasah. Tatar Pasundan: Jurnal Diklat Keagamaan, 13 (2), 220-229

Alwi, Syafaruddin. (2001), Manajemen Sumber Daya Manusia, Strategi Keunggulan Kompetitif,
Yogyakarta: Badan Penerbit Fakultas Ekonomi.

Arikunto, S. (2002). Prosedur Penelitian. Jakarta: Rineka Cipta.

Buto, Zulfikar Ali. (2016). Pengembangan Kompetensi Profesionalisme Guru Pai Di Aceh. Miqot 15 (2), 370-389

Depag RI. (2001). Kendali Mutu Pendidikan Agama Islam. Jakarta: Dirjen Pembinaan Kelembagaan Agama Islam.

Fakhruddin, Agus. (2011). Prinsip-Prinsip Manajemen Pendidikan Islam dalam Konteks Pendidikan Persekolahan. Jurnal Pendidikan Agama Islam: Ta'lim, 9 (2), 199-212

Fakhrudin, Agus. (2011). Prinsip-Prinsip Manajemen Pendidikan Islam. Jurnal Pendidikan Agama Islam: Ta'lim, 9 (2), 199-212

Fakhruddin, Agus. (2014). Urgensi Pendidikan Nilai untuk Memecahkan Problematika Nilai dalam Konteks Pendidikan Persekolahan. Jurnal Pendidikan Agama Islam: Ta'lim, 12 (1), 79-96

Handoko, T Hani. (2001). Manajemen Personalia dan Sumberdaya Manusia,Edisi Kedua. Yogyakarta $\bullet$ BPFE.

John M. Ivancevich, Robert Konopaske. (2008). Perilaku dan manajemen organisasi jilid 1, Jakarta: Erlangga.

Mathis Robert L dan Jackson John H. (2002). Human resoursce 
management, alih bahasa, Jakarta : Salemba empat.

Mulyadi, Idris. (2020). Kompetensi Pengawas dalam Pelaksanaan Supervisi Akademik. Jurnal Pendidikan Ceding 1 (1), 1-8

Nopriyani, Ismi Fenty. (2016). Problematika supervisi akademik pengawas PAI dalam meningkatkan kompetensi kepemimpinan Guru Pendidikan Agama Islam: Studi Kasus di SD Negeri Kecamatan Padang Ulak Tanding Kabupaten Rejanglebong Propinsi Bengkulu. Tesis

Nurmayuli, N. (2018). Realita, Problematika, dan Harapan dalam Supervisi Pendidikan. Jurnal Almabhats, 3 (1), 59-85

Rofiki, Moh. (2019). Urgensi Supervisi Akademik dalam Pengembangan Profesionalisme Guru Di Era Industri 4.0. Indonesian Journal of Basic Education, [S.1.], v. 2, n. 3, p. 502 - 514, nov. 2019. ISSN 2615-8523.

Sarnoto, A. Zain. (2012). Urgensi Supervisi Pengajaran dalam meningkatkan profesionalisme Guru PAI. Statement, 2 (3), 81-92

Supriadi, Dedi. (1999). Mengangkat Citra dan martabat Guru. Yogyakarta: Adicita Karya Nusa.

Sudjana, Nana. (2012)a. Pengawas dan Kepengawasan: Memahami Tugas Pokok, Fungsi, Peran dan Tanggung Jawab Sekolah. Bekasi: Binamitra Publishing.
Sudjana, Nana. (2012)b. Supervisi Pendidikan: Konsep dan Aplikasinya bagi Pengawas Sekolah. Bekasi: Binamitra Publishing.

Tafsir, Ahmad. (1991). 11mu Pendidikan dalam Perspektiflslam, Bandung: Rosda Karya,.

Tyson S, Jackson T. (2001). Organizational Behaviour (Perilaku Organisasi).Yogyakarta: Andi.

Yusuf, M Kadar. (2013). Tafsir Tarbawi (Pesan-pesan al-qur'an tentang pendidikan). Jakarta: Amzah. 